\title{
A study on relationship of brand characteristics and customer satisfaction with brand loyalty
}

\author{
Ebrahim Zarepour Nasirabadi $^{\mathbf{a}^{*}}$ and Mohsen Nazem Bokaei ${ }^{\mathrm{b}}$
}

${ }^{a}$ Department of Business Management, Science and Research Branch Islamic Azad University, Tehran, Iran ${ }^{b}$ Department of Business Management, Shahed University, Tehran, Iran

\section{H R O N I C LE A B T R A C T}

\section{Article history:}

Received March 12, 2013

Received in revised format

10 June 2013

Accepted 22 June 2013

Available online

June 252013

Keywords:

Brand Loyalty

Brand Name

Corporate Reputation

Promotion

Price

Brand Image

Customer Satisfaction

\begin{abstract}
Brands are considered as valuable assets of a company both economically and strategically. Thus, having customers who are loyal to a brand is one of the main goals of businesses companies. Identifying and anticipating the customers' needs are vital to the enterprises gaining competitive advantage and market segmentation. Maintaining and enforcing customers' loyalty is a strategic challenge for companies seeking to keep and promote their competitive status in the market. High brand loyalty of the customers generates competitive advantage for the company and it increases the income and decreases the costs of marketing. In addition to increasing the market share, loyalty allows to ask for higher prices compared with its competitors. This study seeks to investigate the factors influencing customer loyalty to sport brands. The statistical population of this research was Tehran city. Using simple cluster sampling, 502 customers of four known brand sports, i.e. Nike, Puma, Adidas, Reebok, and Fila were chosen. Furthermore, a questionnaire, which assessed seven variables including reputations, brand name, brand image, brand loyalty, customer satisfaction, promotion and the price was used and the hypotheses were analyzed using statistical tests such as KolmogorovSmirnov test (K-S test), Spearman correlation, simultaneous linear regression and binomial test. The findings suggested that the brand name has a strong correlation with brand loyalty. Moreover, variables such as reputation, brand image, customer satisfaction, price and promotions also have positive and significant effect on the brand loyalty.
\end{abstract}

\section{Introduction}

Many companies, especially those working in the sports industry normally try to increase brand loyalty of their customers. Brand loyalty is a conscious or unconscious decision realized in consistent purchase intention or behavior of a particular brand. Brand loyalty is the primary objective of marketing (Reichheld \& Sasser, 1990). In marketing, brand loyalty entails consumer's commitment to re-purchase, using other services and learning positive behaviors towards the brand. This means that the decision to re-purchase depends on factors such as trust and performance, product quality and services (Chaudhuri \& Holbrook, 2001).

*Corresponding author.

E-mail addresses: zarepoor313@gmail.com (E. Zarepour Nasirabadi) 
Given the fact that loyal customers are the key component of corporate success, developing customer loyalty is a concept, which has been a subject of growing attention in today' businesses. Loyal customers normally purchase more, pay higher prices and word-of-mouth marketing influences them, positively. As a result, firms look for identifying and managing effective techniques to create loyalty commonly known as loyalty plans. Today, we live in a society in which demands of the business are higher than any other time. No business other than state organizations can survive without loyal customers. Furthermore, given the fact that the customers' expectations increase, firms are required to go beyond the customers' primary requirements and meet their expectations as well. They have to shift their concentration from mere fulfilling of the customers' demands to developing customers' loyalty and trust by creating long-term relationships, which are mutually beneficial to the parties (Dick \& Basu, 1994).

A number of studies on grocery stores have disclosed that the customers who participated in the loyalty plans represented higher loyalty than other customers did. However, most of the customers do not change their purchase behavior after participating in the loyalty plans. The purpose of these plans, thus, is to retain loyal customer and negotiate a deal with them. The studies of Shoemaker and Lewis show that creating and maintaining customer loyalty regardless of attitudinal aspects would be a tedious task (Dick \& Basu, 1994). Several studies have stated the relative importance of both behavioral and attitudinal characteristics of the loyalty and firms need to address both aspects to achieve true loyalty.

The aim of this study is to investigate and identify factors influencing customer loyalty, including product quality, brand image, shopping environment, price and promotion, on consumers of sportswear brands such as Nike, Adidas, Puma and Reebok.

\section{Literature review and hypotheses}

\subsection{Brand loyalty}

There have been various definitions for customer's loyalty such as the reaction of a customer to certain brands, services, shops and categories of products and activities. Others, however, characterize loyalty as the behavioral response made at any time via decision making or considering a variety of brands in a psychological process. A comprehensive definition of loyalty defines loyalty as the profound commitment to re-purchase a preferred product or service. Such purchase action is repeated in the future and may lead to the re-purchase of a certain brand or a set of brands in face of outside situational influences and attempts made to substitute or alter the behavior. There are other definitions for loyalty in terms of patterns of previous purchases. Many marketing researchers and consultants believe that an attitudinal commitment is necessary to induce true loyalty to a brand. These attitudes could be computed by inquiring people about their preference, beliefs and commitment toward a certain brand.

\subsection{Factors influencing brand loyalty}

\subsubsection{Brand name}

Compared to unknown brand names, familiar brands can increase the products advantages and promote higher sales (Keller, 2003). When there are unfamiliar brand names in the market; consumers tend to trust the familiar brands. Such famous brand names and their images are fixed in consumer's mind. They may encourage purchase and re-purchase behavior though price cuts may change their behavior. Cadogan and Foster (2000) argued that a brand could create an emotional and personal connection, which distinguishes that brand. It is necessary for brands with only minor physical differences distributed in the same social environment to create a vivid image in customers' 
mind. On the other hand, popular magazines and the press masterfully attempt to propagate and promote these images to give recognition to a brand (Colborne, 1996). Consumers are usually able to evaluate a product or brand and their features (Keller, 2003). It should be noted that such information is essential for marketing managers because it helps them make decisions on product positioning, changes and various advantages. According to Kohl and Thakur (1997) brand name is to create a brand image or develop an identity, which could be highly expensive and time-consuming. Brands are vital for attracting customers, making purchase and affecting re-purchase. Consumers tend to perceive products from an overall perspective associated with the brand, features and experience of buying and using the product.

$\mathbf{H}_{1}$ : There is a positive relationship between brand name and loyalty of the consumers of sportswear.

\subsection{2 - Corporate reputation}

Attitudes are of particular interest to social scientists because they are important determinants of future behavior (Fishbein \& Ajzen, 1975). It has been a long debates over the definition of brand loyalty, although a general agreement about the serious effect of brand reputation can be found (Jacoby \& Chestnut, 1978).

$\mathbf{H}_{2}$ : There is a positive relationship between corporate reputation and loyalty of the consumers of sportswear.

\subsubsection{Price}

According to Cadogan and Foster (2000) price is probably the most important factor for consumers. Loyal customers are willing to pay higher price for their favorite brands, thus, their buying intention is not solely affected by the price. Moreover, customers compare the price and value of their favorite brand with other brands and hold strong beliefs about it (Evans et al., 1996).

Consumers' satisfaction is in part the result of comparing prices, expense and perceived value. If the perceived value of a product is bigger than its expenses, the consumers do not hesitate to buy that product. Loyal customers are likely to pay higher prices to prevent changing brand since they cannot afford the high risks associated with brand changing (Yoon \& Kim, 2000).

Basically, long-term loyalty and the services offered to loyal customers increase the tolerance of the customers towards higher prices. Price becomes a primary key in consumer judgment about the value of the product and their assessment of the value of the goods at retail shops. Price becomes a focal point in consumer judgment about the value of the product and their assessment of the value of the goods at retail shops (De Ruyter \& Bloemer, 1999). According to Bucklin (1998), price can significantly influence the choice of the consumers and their purchase behavior. He also emphasized that price cuts and discounts accelerates the process of finding required products for the families and thus increases the chance for replacement of other brands.

Price indicates the relationship of exchange among products paid for each other (the amount or index is paid for different products and products are evaluated against that). Awareness of the prices is described as finding the best value for the purchase or sale of products or services. In addition, consumers evaluate the market price against their own reference price and make their decision about the retail prices accordingly (Sprotles \& Kendall, 1986).

$\mathbf{H}_{3}$ : There is a positive relationship between the price and loyalty of consumers of sportswear 


\subsubsection{Brand Image}

Brand image is perceived as the mental image of the customers based on the provided recommendations. Brand image is the balance of symbolic perceptions where the customers relate to the special features of the product of services. It is a representation of the brand in the customer's mind, which is associated with the recommendations, or a set of perceptions about the brand. As such, it can be defined as the rational or emotional perception of the customer associated with a certain name or brand. In commercial markets, the brand image is expected to play an essential role, especially where it is difficult to distinguish the products or services based on concrete quality features. Studies of Selnes (1993), Zeithaml (1988) and Zins (2001) recommend that brand image can influence the customer loyalty. This lays the foundation for the next hypothesis.

$\mathbf{H}_{4}$ There is a positive relationship between the brand image and loyalty of the consumer of sportswear.

\subsubsection{Customer Satisfaction}

Despite the fact that customer satisfaction and brand reputation have two different constructs, they are closely related. They also expected to affect the future behavior and loyalty of customers (Oliver, 1980). Various studies have shown the relationship between satisfaction and loyalty. Various studies have shown the relationship between satisfaction and loyalty. Fornel studied 27 businesses and observed a high correlation between satisfaction and loyalty ranging from 0.17 (in department stores) to 0.66 (in television program). Cronin and Taylor (1992) studied four enterprises and found a strong relationship between satisfaction and loyalty ranging from 0.36 (in fast foods) to 0.837 (in Laundromats). As such, the relationship between loyalty and satisfaction is expected to depend on product features or main services.

$\mathbf{H}_{5}$ : There is a positive relationship between customer satisfaction and loyalty in consumers of sportswear.

\subsubsection{Promotion}

Promotion is a marketing factor and it has a relationship with consumers and includes the use of advertising in business. It is the impersonal presentation of information in mass media about a product, a brand name, a company or a shop and it can significantly influence the reaction, beliefs and attitude of the customers toward the products and brands and change their purchase behavior (Evans et al., 1996). This means that the promotion induced by the advertisement can help create ideas or perceptions in the mind of the consumers and highlight the distinction of products against other brands. According to Rowley (1998), promotion is an important element in a company's marketing strategy. It is used to establish relationship with the customers with regard to the products and it is a method to encourage the purchase or sale of a product or service.

$\mathbf{H}_{\mathbf{6}}$ : There is a positive relationship between promotion and loyalty of the consumers of sportswear.

\section{Methodology}

\subsection{Population and sample}

The statistical population of this study was the city of Tehran and cluster sampling was conducted in 5 different parts by dividing the city into the north, south, east, west and central regions. A questionnaire was used for the purpose of data gathering. The reliability and validity of the questionnaire had been confirmed using Cronbach's alpha (As shown in Table 1), which showed a high degree of validity and reliability. 
Table 1

Reliability of brand loyalty variable

\begin{tabular}{cccccccc}
\hline Variables & $\begin{array}{c}\text { Brand } \\
\text { Name }\end{array}$ & $\begin{array}{c}\text { Corporate } \\
\text { Reputation }\end{array}$ & Price & $\begin{array}{c}\text { Image } \\
\text { Brand }\end{array}$ & Promotion & $\begin{array}{c}\text { Customer } \\
\text { Satisfaction }\end{array}$ & $\begin{array}{c}\text { Brand } \\
\text { Loyalty }\end{array}$ \\
\hline Cronbach's alpha & 0.88 & 0.78 & 0.80 & 0.81 & 0.85 & 0.75 & 0.75 \\
\hline
\end{tabular}

As shown in Table 2, 287 subjects were men, 212 were women, and they mainly fell into 20-30 and 30-40 age groups. The majority of them used sportswear with the brands of Puma, Adidas, Reebok and Fila respectively.

Table 2

Descriptive statistics

\begin{tabular}{cccc}
\hline Cognitive variables & & Number & Frequency \\
\hline \multirow{2}{*}{ Gender } & Men & 290 & 57.8 \\
& Women & 212 & 42.2 \\
\hline \multirow{3}{*}{ Age } & From 16 to 20 & 13 & 2.6 \\
& From 20 to 30 & 218 & 43.4 \\
& From 30 to 40 & 191 & 38 \\
& From 40 to 50 & 48 & 9.5 \\
& More than 50 & 34 & 6.5 \\
\hline \multirow{2}{*}{ Brand } & Nike & 82 & 16.4 \\
& Adidas & 130 & 26 \\
& Puma & 163 & 32 \\
& Reebok & 98 & 20 \\
\hline
\end{tabular}

Table 3 shows that seven independent variables of brand loyalty were gathered through questionnaires. Likert scale was used in the questionnaire (1 strongly disagree, 2 disagree, 3 neutral, 4 agree, 5 strongly agree). The results show that the product quality is the most important factor. In Iran, the quality of the product is the main factor influencing the brand loyalty of the customers.

\subsection{Testing the Hypotheses}

\section{Kolmogorov-Smirnov Test}

Before using correlation tests, it must first be ensured that the variables have been normally distributed. If the variables are normal, Pearson correlation will be appropriate; otherwise, the Spearman test should be used. Kolmogorov-Smirnov, which is a nonparametric test, was used to check whether the variables were normal. SPSS software was used to calculate the test statistics. If the value of the test statistic is more than $5 \%$, the null hypothesis regarding the normal distribution of the target variable will be accepted with $95 \%$ reliability. The results for normal distribution of the variables are presented in Table 3.

\section{Table 3}

Kolmogorov-Smirnov Test

\begin{tabular}{lcccc}
\hline Variables & Number & Kolmogorov-Smirnov- Z & sig & Test result \\
\hline Corporate reputation & 502 & 2.52 & 0.000 & abnormal \\
Image brand & 502 & 3.05 & 0.000 & abnormal \\
Brand name & 502 & 2.82 & 0.000 & abnormal \\
Customer satisfaction & 502 & 2.27 & 0.000 & abnormal \\
Promotion & 502 & 2.19 & 0.000 & abnormal \\
Price & 502 & 2.81 & 0.000 & abnormal \\
Brand loyalty & 502 & 2.71 & 0.000 & abnormal \\
\hline
\end{tabular}


According to Table 3, all variables are abnormal. Thus, we will use Spearman, which is a nonparametric test, to test our hypotheses. Given the nonparametric nature of our variables, we used Spearman's correlation coefficient to test our hypotheses.

\section{Table 4}

The results of Spearman correlation coefficient and the mean of the variables

\begin{tabular}{|c|c|c|c|c|c|c|c|c|c|}
\hline Variables & mean & SD & 1 & 2 & 33 & 4 & 5 & 6 & 7 \\
\hline Corporate reputation & 3.32 & 0.692 & 1 & & & & & & \\
\hline Image brand & 3.47 & 0696 & $0.521 * *$ & 1 & & & & & \\
\hline Brand name & 3.69 & 0.741 & $0.429 * *$ & $0.561^{* *}$ & 1 & & & & \\
\hline Customer satisfaction & 3.27 & 0.673 & $0.420 * *$ & $0.392 * *$ & $0.334 * *$ & 1 & & & \\
\hline Promotion & 3.41 & 0.732 & $0.416^{* *}$ & $0.389 * *$ & $0.390 * *$ & $0.487 * *$ & 1 & & \\
\hline Price & 3.24 & 0.875 & $0.489 * *$ & $0.461^{* *}$ & $0.454 * *$ & $0.517 * *$ & $0.472 * *$ & 1 & \\
\hline Brand loyalty & 3.02 & 0.836 & $0.690 * *$ & $0.438 * *$ & $0.401 * *$ & $0.442 * *$ & $0.408 * *$ & $0.629 * *$ & 1 \\
\hline
\end{tabular}

As shown in the above table, the correlation of the variables was evaluated at $95 \%$ reliability level and all hypotheses were confirmed.

\section{Finding}

Based on the findings of Table 4, there is a meaningful relation between brand loyalty and corporate reputation $(\mathrm{r}=0.690)$, There is also significant relation between brand image and brand loyalty ( $\mathrm{r}=0.438)$ and also between brand name and brand loyalty ( $\mathrm{r}=0.401)$, There is a meaningful relation between customer relation and brand loyalty $(\mathrm{r}=0.442)$ and between promotion and brand loyalty $(\mathrm{r}=0.408)$ and between price and brand loyalty $(\mathrm{r}=0.629)$.

\section{Conclusion}

The demographic characteristics of respondents indicate that most of them were young (470 people were 16-40 years old). Furthermore, male respondents constituted $57.8 \%$ and female respondents constituted $42.2 \%$ of the participants. Such a population, enjoying the index of youth, can be a good example of consumers who, based on the reviewed literature, have bought and used the products of four companies, namely Puma, Nike, Adidas, Reebok and Fila; therefore, they are a proper sample for the purpose of this study. According to Table 2, the brands mostly bought and used are Puma (32\%), Adidas (26\%), Reebok (20\%), Nike (16.4\%) and Fila (5.6\%) respectively.

Hypothesis 1: The relationship between brand name and loyalty of the consumers of sportswear was confirmed. It is consistent with the findings of Keller (2003), Cadogan and Foster, (2000), Calbourne (1996) and Kohl and Thakor (1997).

Hypothesis 2: The relationship between corporate reputation and loyalty of the consumers of sportswear was confirmed. The results are in accordance with the studies of Fishbein and Ajzen (1975) and Jacobyand Chestnut (1978).

Hypothesis 3: The relationship between price and loyalty of the consumers of sportswear was confirmed and it is compatible with the results of Cadogan and Foster (2000) and Bucklin (1998).

Hypothesis 4: The relationship between brand image and loyalty of the consumers of sportswear was confirmed. and it is consistent with the findings of Selnes (1993) Zeithaml (1988) and Zins (2001).

Hypothesis 5: The relationship between customer satisfaction and loyalty of the consumers of sportswear was confirmed. It is in keeping with the findings of Cronin and Taylor (1992) and Oliver (1980). 
Hypothesis 6: Finally, the relationship between promotion and loyalty of the consumers of sportswear was confirmed and it is consistent with the studies of Rowley (1998).

\section{References}

Brandchannel.com (2006) (http://www.brandchannel.com), Accessed 18 August 2006.

Bucklin, R. E., Gupta, S., \& Siddarth, S. (1998). Determining segmentation in sales response across consumer purchase behaviors. Journal of Marketing Research, 189-197.

Cadogan, J. W., \& Foster, B. D. (2000) Relationship Selling and Customer Loyalty: An Empirical Investigation. Marketing Intelligence and Planning, 18, 185-199.

Chaudhuri, A., \& Holbrook, M. B. (2001). The chain of effects from brand trust and brand effect to brand performance: The role of brand loyalty. Journal of Marketing, 65, 81-93.

Colborne, R. (1996). Visual Merchandising: The Business of Merchandise Presentation. Delmar Publisher Albany: New York.

Cretu, A. E., \& Brodie, R. J. (2007). The influence of brand image and company reputation where manufacturers market to small firms: A customer value perspective. Industrial Marketing Management, 36(2), 230-240.

De Ruyter, K., \& Bloemer, J. (1999). Customer loyalty in extended service settings: the interaction between satisfaction, value attainment and positive mood. International Journal of Service Industry Management, 10(3), 320-336.

Dick, A. S., \& Basu, K. (1994). Customer loyalty: toward an integrated conceptual framework. Journal of the academy of marketing science, 22(2), 99-113.

Evans, M., Moutinho, L., \& Raaij, W. F. V. (1996). Applied Consumer Behavior. Addison-Wesley: Harlow.

Gee, R., Coates, G., \& Nicholson, M. (2008). Understanding and profitably managing customer loyalty. Marketing Intelligence \& Planning, 26(4), 359-374.

Gómez, B. G., Arranz, A. G., \& Cillan, J. G. (2006). The role of loyalty programs in behavioral and affective loyalty. Journal of Consumer Marketing,23(7), 387-396.

Heskett, J. L. (2002). Beyond customer loyalty. Managing Service Quality,12(6), 355-357.

Huddleston, P., Whipple, J., \& Van Auken, A. (2004). Food store loyalty: Application of a consumer loyalty framework. Journal of Targeting, Measurement and Analysis for Marketing, 12, 213-230.

Jacoby, J., \& Chestnut, R. W. (1978). Brand loyalty: Measurement and management (p. 157). New York: Wiley.

Keller, K. L. (2003) Strategic Brand Management: Building, Measuring and Managing Brand Equity. Prentice Hall: New Jersey.

Kohli, C., \& Thakor, M. (1997) Branding consumer goods: Insights from theory and practice. Journal of Consumer Marketing, 14, 206-219.

McMullan, R., \& Gilmore, A. (2008). Customer loyalty: an empirical study. European Journal of Marketing, 42(9/10), 1084-1094.

Oliver, R. L. (1980). A cognitive model of the antecedents and consequences of satisfaction decisions. Journal of marketing research, 460-469.

Reichheld, F. F., \& Sasser, W. E. Jr. (1990). Zero defections: Quality comes to services, Harvard Business Review, (September-October), 105-111.

Rowley, J. (1998). Promotion and marketing communications in the information marketplace. Library Review, 47(8), 383-387.

Sprotles, G. B., \& Kendall, E. L. (1986). A Methodology for Profiling Consumers' Decision-Making Styles. Journal of Consumer Affairs, 20(2), 267-279.

Selnes, F. (1993). An examination of the effect of product performance on brand reputation, satisfaction and loyalty. European Journal of marketing, 27(9), 19-35.

Yoon, S. J., \& Kim, J. H. (2000). An empirical validation of a loyalty model based on expectation disconfirmation. Journal of Consumer Marketing, 17(2), 120-136. 
Zeithaml, V. A. (1988). Consumer perceptions of price, quality, and value: a means-end model and synthesis of evidence. The Journal of Marketing, 2-22.

Zins, A. H. (2001). Relative attitudes and commitment in customer loyalty models: some experiences in the commercial airline industry. International Journal of Service Industry Management, 12(3), 269-294. 